University of Nebraska - Lincoln

DigitalCommons@University of Nebraska - Lincoln

Agronomy \& Horticulture -- Faculty Publications

Agronomy and Horticulture Department

2015

\title{
Patch Burning: Implications on Water Erosion and Soil Properties
}

\author{
Altingul Ozaslan Parlak \\ Canakkale Onsekiz Mart University, Turkey \\ Mehmet Parlak \\ Canakkale Onsekiz Mart University, Turkey \\ Humberto Blanco-Canqui \\ University of Nebraska-Lincoln, hblanco2@unl.edu \\ Walter H. Schacht \\ University of Nebraska-Lincoln, wschacht1@unl.edu \\ John A. Guretzky \\ University of Nebraska-Lincoln, jguretzky2@unl.edu
}

See next page for additional authors

Follow this and additional works at: https://digitalcommons.unl.edu/agronomyfacpub

Part of the Agricultural Science Commons, Agriculture Commons, Agronomy and Crop Sciences Commons, Botany Commons, Horticulture Commons, Other Plant Sciences Commons, and the Plant Biology Commons

Parlak, Altingul Ozaslan; Parlak, Mehmet; Blanco-Canqui, Humberto; Schacht, Walter H.; Guretzky, John A.; and Mamo, Martha, "Patch Burning: Implications on Water Erosion and Soil Properties" (2015). Agronomy \& Horticulture -- Faculty Publications. 1112.

https://digitalcommons.unl.edu/agronomyfacpub/1112

This Article is brought to you for free and open access by the Agronomy and Horticulture Department at DigitalCommons@University of Nebraska - Lincoln. It has been accepted for inclusion in Agronomy \& Horticulture -Faculty Publications by an authorized administrator of DigitalCommons@University of Nebraska - Lincoln. 


\section{Authors}

Altingul Ozaslan Parlak, Mehmet Parlak, Humberto Blanco-Canqui, Walter H. Schacht, John A. Guretzky, and Martha Mamo 
Published in Journal of Environmental Quality 44 (2015), pp 903-909.

doi:10.2134/jeq2014.12.0523

PubMed ID: 26024270

Copyright (C) American Society of Agronomy, Crop Science Society of America, and Soil Science Society of America. Used by permission.

Submitted 7 December 2014; accepted 30 January 2015; published online 27 March 2015.

\title{
Patch Burning: Implications on Water Erosion and Soil Properties
}

\author{
Altingul Ozaslan Parlak, ${ }^{1}$ Mehmet Parlak, ${ }^{2}$ \\ Humberto Blanco-Canqui, 3 Walter H. Schacht, 3 \\ John A. Guretzky, ${ }^{3}$ and Martha Mamo ${ }^{3}$ \\ 1 Canakkale Onsekiz Mart University, Faculty of Agriculture, \\ Department of Field Crops, Canakkale, Turkey \\ 2 Canakkale Onsekiz Mart University, Lapseki Vocational School, \\ Canakkale, Turkey \\ 3 University of Nebraska-Lincoln, Department of Agronomy \\ and Horticulture, Lincoln, NE 68583 \\ Corresponding author - H. Blanco-Canqui, email hblanco2@unl.edu
}

\begin{abstract}
Patch burning can be a potential management tool to create grassland heterogeneity and enhance forage productivity and plant biodiversity, but its impacts on soil and environment have not been widely documented. In summer 2013, we studied the effect of time after patch burning ( 4 mo after burning [recently burned patches], 16 mo after burning [older burned patches], and unburned patches [control]) on vegetative cover, water erosion, and soil properties on a patch-burn experiment established in 2011 on a Yutan silty clay loam near Mead, NE. The recently burned patches had $29 \pm 8.0 \%$ (mean \pm SD) more bare ground, $21 \pm 1.4 \%$ less canopy cover, and $40 \pm 11 \%$ less litter cover than older burned and unburned patches. Bare ground and canopy cover did not differ between the older burned and unburned patches, indicating that vegetation recovered. Runoff depth from the older burned and recently
\end{abstract}


burned patches was 2.8 times (19.6 \pm 4.1 vs. $7.1 \pm 3.0 \mathrm{~mm}$ [mean $\pm \mathrm{SD}]$ ) greater than the unburned patches. The recently burned patches had 4.5 times greater sediment loss $\left(293 \pm 89\right.$ vs. $\left.65 \pm 56 \mathrm{~g} \mathrm{~m}^{-2}\right)$ and 3.8 times greater sediment-associated organic C loss $\left(9.2 \pm 2.0\right.$ vs. $\left.2.4 \pm 1.9 \mathrm{~g} \mathrm{~m}^{-2}\right)$ than the older burned and unburned patches. The recently burned patches had increased daytime soil temperature but no differences in soil compaction and structural properties, dissolved nutrients, soil C, and total $\mathrm{N}$ concentration relative to older burned and unburned patches. Overall, recently burned patches can have reduced canopy and litter cover and increased water erosion, but soil properties may not differ from older burn or unburned patches under the conditions of this study.

Abbreviations: EC, electrical conductivity

Patch burning can be a potential grassland management strategy using prescribed fire and grazing livestock. It consists of using prescribed fire to burn select patches within a grazing unit to create heterogeneity in otherwise homogeneous units (Winter et al., 2011). Because of the high quality and availability of new plant growth on the burned patches, grazing livestock preferentially graze the burned patches (Fuhlendorf and Engle, 2004; Teague et al., 2008). The burning treatment is shifted from area to area within the grazing unit from year to year to create a mosaic of different vegetation structures and physiological growth stages. This shifting of burned areas can be important to increase spatial and temporal heterogeneity of forage quality and quantity compared with homogeneous or conventional systems with reduced biodiversity and lower productivity. Potential benefits of patch burning include (i) increased forage quality, (ii) enhanced plant diversity, (iii) improved wildlife habitat, and (iv) reduced proliferation of invasive plant species and wildfire hazards (Fuhlendorf and Engle, 2004).

Patch burning may contribute to revitalization and stimulation of plant growth by recycling nutrients from previous vegetation, stimulating tillering, and reducing excessive plant litter accumulation (Johnson and Matchett, 2001; Augustine et al., 2010). Burning reduces grassland canopy cover, which allows more light to reach the soil surface and increase soil temperature (Vermeire et al., 2005; Teague et al., 2010). Rapid warming of soil in spring and improved nutrient cycling after periodic patch burns can stimulate plant growth and increase forage production (Johnson and Matchett, 2001; Augustine et al., 2010). 
Although patch burning may have beneficial effects on forage production and system spatial heterogeneity, it is important to consider its implications on soil and the environment. The interactive effects of patch burning and grazing on soil properties have not been widely discussed. Burning followed by concentration of grazing livestock on a burned patch has the short-term effect of further reducing vegetation cover and mass and may adversely affect soil properties and processes. The combination may reduce water infiltration and soil organic $\mathrm{C}$ and nutrient pools and increase risks of water and wind erosion, soil compaction, and soil structure deterioration of the patch (Teague et al., 2008; Schmalz et al., 2013).

Patch burning may particularly increase risks of water erosion because of reduced plant cover in the year of the fire and concentrated grazing (Teague et al., 2008, 2010). The effect of increased plant cover on reducing runoff and sediment yield as well as enhancing soil microbial processes is well recognized (Johansen et al., 2001; Savadogo et al., 2007), but specific studies reporting patch burning effects on water erosion are few. Fires alone can have significant impacts on soil chemical, physical, mineralogical, and biological properties (Robichaud, 2000). In particular, fires cause partial or complete combustion of organic matter, which may degrade soil structure and increase bulk density. In eastern Nebraska, repeated prescribed burning reduced water infiltration but generally had no effect on soil bulk density, $\mathrm{pH}$, electrical conductivity (EC), total N, and organic matter concentrations (Schacht et al., 1996).

The few studies specifically assessing soil response to patch burning have found small or no significant changes in soil properties. In the Rolling Plains of north-central Texas, Teague et al. (2008) reported variable effects on soil properties after $4 \mathrm{yr}$ of patch burning of a grazed, open grassland site. Patch burning had no effect on soil aggregate stability and bulk density; however, compared with nonburned sites, water infiltration of the burned patches was greater in years 4 and 5 and lower in year 6 , and penetration resistance was lower in year 4 . In the same region, Teague et al. (2010) reported that summer patch burning in continuously and rotationally stocked pastures had no effect on soil bulk density, penetration resistance, soil temperature, aggregate stability, water infiltration rates, and soil organic $\mathrm{C}$ and total soil $\mathrm{N}$ concentrations in each year of a 4-yr study. The authors suggested that adequate rainfall received after burns during the study years probably contributed to rapid recovery and regrowth of vegetation, reducing any adverse effects 
on soil properties. Precipitation input after patch burning may be critical to ensure success of this management strategy.

Further assessment of soil and environment response to patch burning is warranted to better understand how this emerging management practice affects soil attributes influencing grassland productivity. The objective of this study was to examine the effects of time (recently burned and older burned patches) after one-time burning on water erosion, soil properties, and vegetation cover characteristics in eastern Nebraska. Our hypothesis was that patch burning followed by concentrated grazing increases water erosion and degrades near-surface soil properties by reducing canopy and litter cover in the short term.

\section{Materials and Methods}

\section{Experiment Description}

This study was conducted on a patch-burn experiment established in 2011 at the University of Nebraska-Lincoln Agricultural Research and Development Center near Mead, NE ( $\left.41^{\circ}{ }^{\circ} 09^{\prime} 03^{\prime \prime} \mathrm{N}, 96^{\circ} 29^{\prime} 57^{\prime \prime} \mathrm{W}\right)$. The experiment occupied a total area of $2.1 \mathrm{ha}$. The dominant soil series at the study site was a Yutan silty clay loam (fine-silty, mixed, superactive, mesic Mollic Hapludalfs). Before the experiment, the study site was under hay management for about $15 \mathrm{yr}$ with no history of burning. Hay was harvested twice per year in late June and late August. The site was on a west-facing slope ranging from 2 to $8 \%$. Vegetation was comprised of a mixture of warm-season and cool-season grasses and some forbs. The dominant warm-season grasses were big bluestem (Andropogon gerardii Vitman), sideoats grama [Bouteloua curtipendula (Michx.) Torr.], indiangrass [Sorghastrum nutans (L.) Nash], and little bluestem [Schizachyrium scoparium (Michx.) Nash]. The dominant cool-season grasses were Kentucky bluegrass (Poa pratensis L.), smooth bromegrass (Bromus inermis Leyss.), and tall fescue [Lolium arundinaceum (Schreb.) S. J. Darbyshire]. The 30-yr mean annual precipitation for the study area was $747 \mathrm{~mm}$. Mean annual precipitation was $425 \mathrm{~mm}$ in 2012 and $675 \mathrm{~mm}$ in 2013. The low mean precipitation in 2012 is due to the prolonged drought that affected the region. Mean annual maximum daily temperature was $16.5^{\circ} \mathrm{C}$, and the mean annual minimum daily temperature was $3.4^{\circ} \mathrm{C}$. 
The experiment was a randomized complete block design with pasture as block and three patch-burn treatments in each pasture: (i) a recently burned patch (4 mo after burning), (ii) an older burned patch (16 mo after burning), and (iii) an unburned patch (control). Patch was the experimental unit, and all patches were equal in size (19.3 by $122 \mathrm{~m})$. In each pasture, the first patch to the north was burned in April 2012, the center patch was burned in April 2013, and the remaining patch was burned in April 2014. Vegetation and soil data were collected in August 2013, which was 16 mo after the north patches were burned (April 2012; older burned patches) and 4 mo after the center patches were burned (April 2013; recently burned patches). The remaining unburned patch in each pasture had not been burned before August 2013 and was used as a control.

Each of the pastures was grazed beginning on 23 May 2012 and 30 May 2013 (50 and $33 \mathrm{~d}$ after burning, respectively). The three patchburn treatments were grazed for $50 \mathrm{~d}$ in 2012 at a stocking rate of 5.0 AUM (animal unit month) ha-1 and $56 \mathrm{~d}$ in 2013 at a rate of 5.3 AUM ha1. Grazing cattle are reported to spend as much as $75 \%$ of their grazing time on the most recently burned patch during the growing season in a patch-burn grazing situation (Fuhlendorf and Engle, 2004). In our study, warm-season grasses had not begun growth at the time of the burns, and the management goal was to provide sufficient growth of the cool-season grass component at the time of cattle stocking so as not to limit intake of forage by the cattle and manage competitiveness of the cool- and warmseason grass components. Regardless, our visual observations during the 2012 and 2013 grazing seasons indicated that cattle concentrated grazing in the most recently burned patch in each plot. In this patch-burn experiment, all experimental units (recently burned, older burned, and unburned) were grazed.

\section{Water Erosion Measurement}

The effect of patch burning on water erosion was studied under simulated rainfall. Before rainfall simulation, vegetation cover characteristics, including canopy cover, bare ground, and litter cover, were determined within each runoff plot by the point-method (Mueller-Dombois and Ellenberg, 1974). In addition, six soil samples using a hand probe were collected around each runoff plot from the 0 - to $10-\mathrm{cm}$ and the 10to $20-\mathrm{cm}$ depth to determine antecedent soil water content before rainfall simulation. 
Simulated rainfall was applied to a runoff plot in each of the nine patches in August 2013 to measure runoff amount and concentration of sediment and sediment-associated nutrients. The runoff plot had dimensions of $0.52 \mathrm{~m}$ by $1.06 \mathrm{~m}$ and was enclosed by metal borders using a rectangular runoff box driven to a 10-cm depth into the soil. A portable rainfall simulator developed by Humphry et al. (2002) was used in this study. Rainfall was applied from a $2.5-\mathrm{m}$ height through a single TeeJet 1/2 HH-SS5oWSQ nozzle (Spraying Systems Co.). The nozzleassociated plumbing, in-line filter, pressure gauge, and electrical wiring were all mounted over a 3- by 3- by 3-m aluminum frame (Humphry et al., 2002). Simulated rainfall using tap water was applied at $62.2 \pm 1.97$ $\mathrm{mm} \mathrm{h}^{-1}$ intensity to each patch for $60 \mathrm{~min}$. The simulated rainfall intensity portrayed a 10-yr return period for the study region. Water supplied had an EC of $0.79 \mathrm{dS} \mathrm{m}^{-1}$ and a pH of 7.4. Rain gauges measured rainfall intensity within each plot.

A PVC pipe cut in half lengthwise was placed at the downslope of each plot to direct runoff from each runoff plot to a plastic bucket placed in a soil pit. Only one runoff sample was collected per run. Total runoff volume was measured at the end of the 1-h rainfall simulation. The total runoff volume and plot dimensions were used to calculate runoff depth. For each simulated rainfall event, time to runoff initiation was also recorded. Runoff subsamples were stored in coolers and transported to the laboratory.

A subsample of runoff ( $1 \mathrm{~L}$ ) was used to determine sediment concentration by the evaporation method (Blanco-Canqui et al., 2004). The runoff subsamples were dried at $60^{\circ} \mathrm{C}$ in an oven to determine sediment concentration and sediment-associated $\mathrm{C}$ and total $\mathrm{N}$ concentration. The oven-dry sediment was finely ground, passed through 0.25 -mm sieve, and analyzed for soil organic $\mathrm{C}$ and total $\mathrm{N}$ by the dry combustion method in a CHN Thermo Scientific Flash analyzer (Nelson and Sommers, 1996).

Another subsample of runoff was taken for the determination of $\mathrm{pH}$, $\mathrm{EC}$, dissolved organic C, dissolved P, and total P. Soil runoff $\mathrm{pH}$ and $\mathrm{EC}$ were determined on unfiltered samples using the Orion $\mathrm{pH}$ meter and a HANNA DiST EC tester, respectively. The runoff $\mathrm{pH}$ was determined on a 1:2 suspension (10 g of soil to $20 \mathrm{~mL}$ of water) (Thomas, 1996), and EC was measured using 1:5 soil/water ratio mixtures (Rhoades, 1996). Dissolved $\mathrm{C}$ and total $\mathrm{P}$ were analyzed in unfiltered runoff samples. Dissolved $\mathrm{P}$ was analyzed in runoff samples filtered through no. 5 Whatman filter paper. Dissolved C concentration was determined on a Shimadzu 
TOC-V CPN analyzer. Total $\mathrm{P}$ was determined after digestion in acid (Bray and Kurtz P1) (Bray and Kurtz, 1945). Total P and dissolved P were analyzed by molybdate method and determined on Genesys 5 spectrophotometer (Murphy and Riley, 1962).

\section{Soil Property Measurements}

At the time of rainfall simulation, penetration resistance and soil temperature were measured for the nine patches. Penetration resistance was determined at 10 random points within each patch for the $0-$ to $7.5-\mathrm{cm}$ soil depth. The penetration resistance was measured using a static hand cone penetrometer (Eijkelkamp), and the values were expressed as cone index by dividing the normal force by the base area of the penetrometer cone (Lowery and Morrison, 2002). At the time of rainfall simulation, soil temperature was measured by soil thermometers inserted into three different soil depths $(1,5$, and $10 \mathrm{~cm})$ between 11:00 and 14:00 h. Similar to penetration resistance measurements, soil temperature was determined for 10 random points within each patch.

Soil cores of $8.2 \mathrm{~cm}$ diameter were collected to a 7.5- $\mathrm{cm}$ depth for the analysis of bulk density, wet aggregate stability, and concentration of soil organic $\mathrm{C}$ and total $\mathrm{N}$. The soil cores were collected from the $\mathrm{o}-\mathrm{to} 7.5-\mathrm{cm}$ soil depth using a hammer-driven sampler. A total of 27 soil cores were taken ( 3 patch-burn dates $\times 3$ replications $\times 3$ depths). To test the hypothesis that one-time patch burning may have affected soil properties only in the upper few centimeters of the soil surface, the $7 \cdot 5-\mathrm{cm}$ depth soil cores were carefully split into three sections in the laboratory, representing the $0-$ to $2.5-\mathrm{cm}, 2.5$ - to $5.0-\mathrm{cm}$, and $5.0-$ to $7.5-\mathrm{cm}$ depth intervals. Bulk density, wet aggregate stability, and concentration of soil organic $\mathrm{C}$ and total $\mathrm{N}$ were determined subsequently on each of these depth increments.

Bulk density was determined by the core method (Grossman and Reinsch, 2002). A portion of the soil core samples was air-dried and used for the determination of wet aggregate stability. Air-dry samples for wet aggregate stability analysis were sieved through $4.75^{-}$and 8 -mm sieves to obtain aggregates between 4.75 and $8 \mathrm{~mm}$ in diameter. Wet aggregate stability was determined on $50 \mathrm{~g}$ of 4.75- to 8-mm air-dry aggregates by the wet sieving method using a mechanical device (Nimmo and Perkins, 2002). The $50 \mathrm{~g}$ of aggregates were placed on top of a stack of sieves with openings 4.75, 2, 1, 0.5, and $0.25 \mathrm{~mm}$ in diameter arranged in descending 
order. The sieves were in water tanks and the top screen sieve was just in contact with water. The aggregates were saturated by capillarity for 10 min and mechanically sieved in the column of water for another 10 min. Then, the aggregates remaining in each sieve were transferred to beakers and oven-dried at $105^{\circ} \mathrm{C}$. Sand correction was performed in each aggregate size fraction. Data on aggregate size and amount were used to compute the mean weight diameter of aggregates (Nimmo and Perkins, 2002). Another portion of the air-dried samples from each depth interval was crushed and roller-milled to determine organic $\mathrm{C}$ and total $\mathrm{N}$ concentration in a $\mathrm{CN}$ analyzer (Vario Max, Elementar Americas) by dry combustion method $\left(900^{\circ} \mathrm{C}\right)$ (Nelson and Sommers, 1996). All statistical analyses were conducted using the GLM procedure in SAS (SAS Institute, 2014). Treatment effects were evaluated by the Duncan test control, and significance was reported at the 0.05 probability level.

\section{Results and Discussion}

\section{Vegetative Cover}

The recently burned patches had less canopy cover, more bare ground, and less litter cover compared with older burned and unburned patches (Fig. 1). On average, recently burned patches had $21 \pm 1.4 \%$ (mean \pm SD) less canopy cover and $29 \pm 8.0 \%$ more bare ground than older burned and unburned patches (Fig. 1). The recently burned patches also had $32 \pm 6.0 \%$ less litter cover than older burned patches and $47 \pm 10.4 \%$ less litter cover than unburned patches. Whereas percent canopy cover and bare ground in older burned patches did not differ from unburned patches, litter cover on older burned patches was $15 \pm 5 \%$ less than unburned patches (Fig. 1), which suggested that litter cover had not completely recovered to the control level after 16 mo. As expected, the unburned plots had the greatest canopy cover ( $97 \pm 2.9 \%)$, the least bare ground $(1.7 \pm 2.9 \%)$, and the greatest litter cover ( $93 \pm 2.9 \%)$.

Significant decreases in canopy and litter cover and increases in bare ground on recently burned patches within patch-burn systems have been documented elsewhere (Fuhlendorf and Engle, 2004; Teague et al., 2010). The small or no differences in vegetation cover between older burned and unburned patches in our study suggest that total plant cover can, in general, return to preburn levels after 1 yr. Even though the 


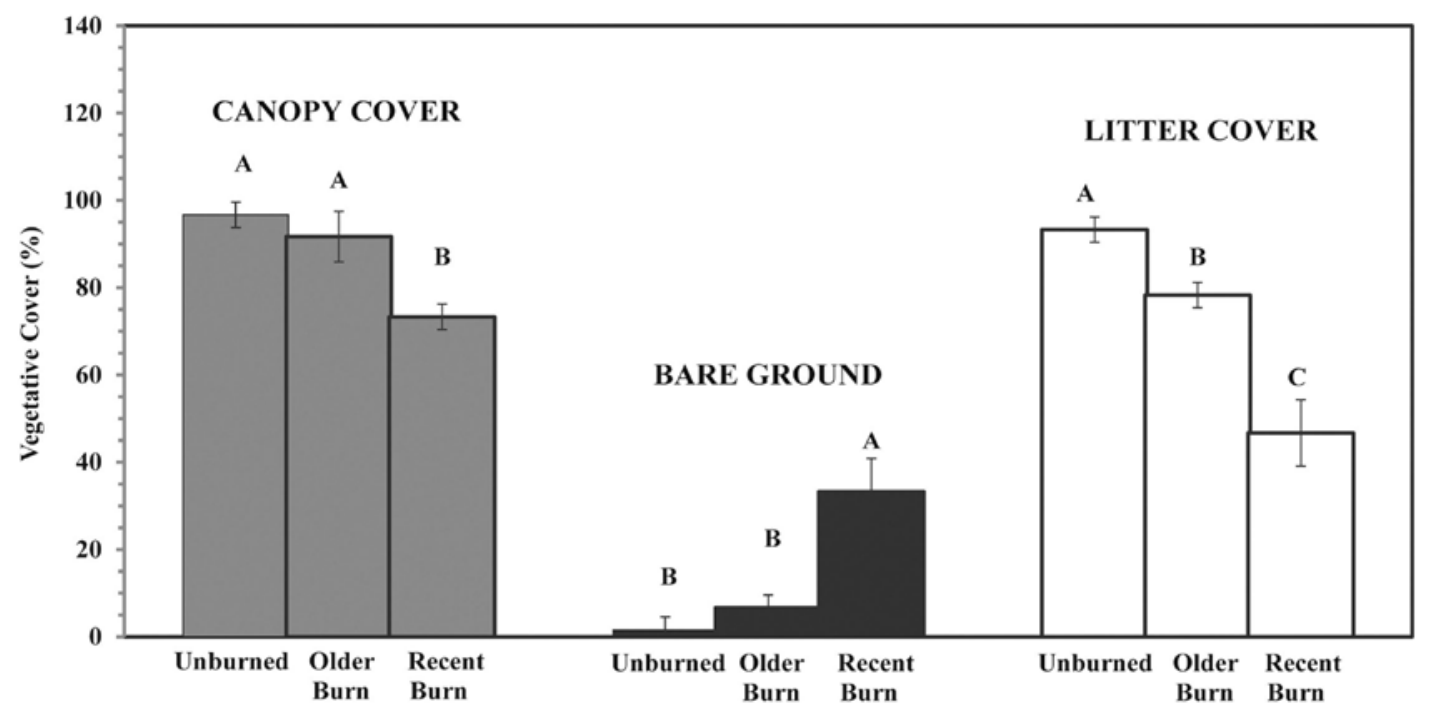

Fig. 1. Patch burning effects on percent canopy cover, bare ground, and litter cover measured 4 mo after burning (recently burned patches) and 16 mo after burning (older burned patches) relative to unburned patches within a patch-burn experiment in eastern Nebraska. Means followed by different uppercase letters within the same soil cover parameter are significantly different. The errors bars are the SD of the mean.

annual precipitation amount in 2012 was $(425 \mathrm{~mm}$ ) lower than the 30yr average $(747 \mathrm{~mm})$, vegetation appeared to recover rapidly after burning. Our results appeared to agree with those of Teague et al. (2010), who reported that herbaceous plant cover and biomass production in patch-burned plots in the Rolling Plains of Texas recovered rapidly and caught up with the level of biomass production in unburned plots within 2 and $3 \mathrm{yr}$.

\section{Water Erosion}

Runoff from the recently burned patches started 6 min earlier than that from older burned patches and 4 min earlier than the unburned patches (Fig. 2A). Runoff depth was in the order: recently burned = older burned $>$ unburned patches. These results indicate that, regardless of burn date, patch burning and the intensive grazing that followed consistently caused an increase in runoff loss compared with patches that were unburned and probably subject to less grazing (Fig. 2B). The burned patches had about 2.7 times $(19.6 \pm 4.1 \mathrm{vs.} 7.1 \pm 3.0 \mathrm{~mm}[$ mean $\pm \mathrm{SD}])$ greater runoff depth than unburned patches (Fig. 2B). 

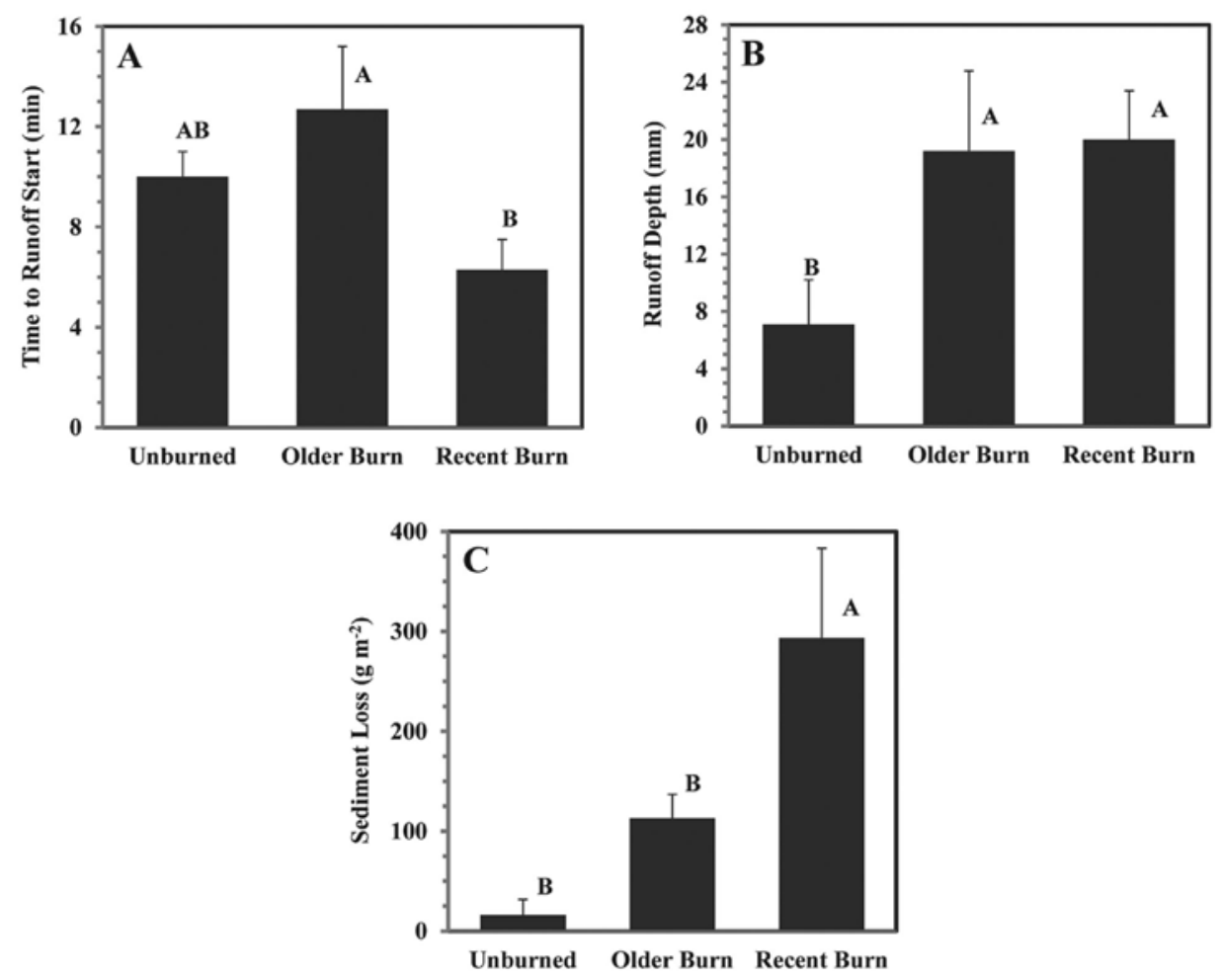

Fig. 2. Patch burning effects on time to runoff start (A), runoff depth (B), and sediment loss (C) measured 4 mo after burning (recently burned patches) and 16 mo after burning (older burned patches) relative to unburned patches within a patchburn experiment in eastern Nebraska. Means followed by different uppercase letters are significantly different. The error bars are the SD of the mean.

Similarly, the recently burned patches lost 3 times more sediment than older burned patches and 15 times more sediment than unburned patches (Fig. 2C). They also had greater losses of sediment-associated soil organic C (Fig. 3A) and total N concentration (Fig. 3B). Sediment-associated soil organic $\mathrm{C}$ concentration losses from recently burned patches was 13 times greater than unburned patches and about 2 times greater than older burned patches (Fig. 3A), but differences between older burned and unburned patches were not significant. Both burn patches lost about 4 times more sediment-associated total $\mathrm{N}$ compared with the unburned patches (Fig. 3B). Results, however, showed that differences in runoff water characteristics (e.g., $\mathrm{pH}$ and EC), as well as concentration of dissolved organic $\mathrm{C}$, dissolved $\mathrm{P}$, and total $\mathrm{P}$ between burn and unburned patches, were not significant (Table 1). 

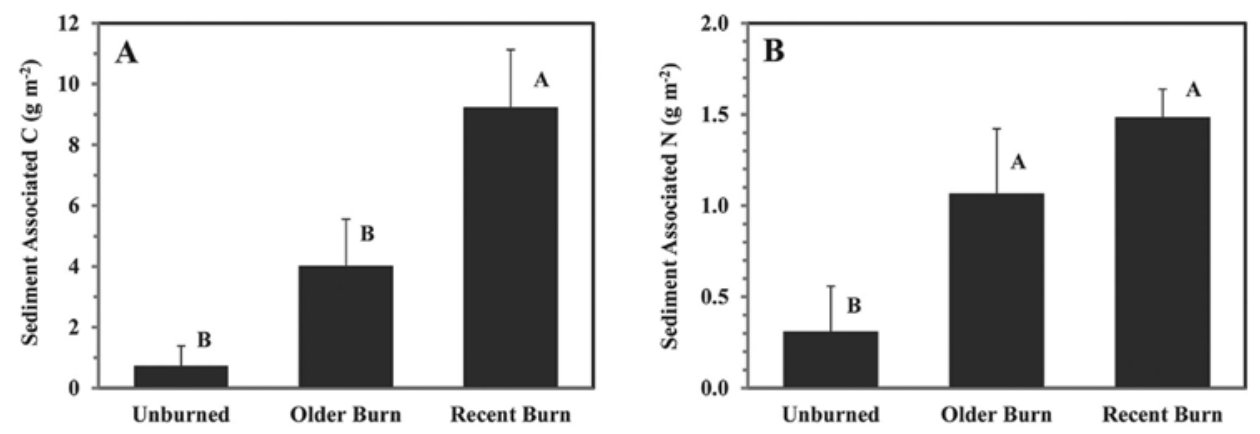

Fig. 3. Patch burning effects on sediment-associated organic C (A) and total N (B) concentration measured 4 mo after burning (recently burned patches) and 16 mo after burning (older burned patches) relative to unburned patches within a patchburn experiment in eastern Nebraska. Means followed by different uppercase letters are significantly different. The error bars are the SD of the mean.

Our hypothesis stating that patch burning increases water erosion by decreasing the amount of canopy cover and litter was supported by our data collected 4 mo after patch burning but not 16 mo after burning. Losses of runoff, sediment, and sediment-associated nutrients were accelerated in recently burned patches. A rainstorm event of $62 \mathrm{~mm} \mathrm{~h}^{-1}$ has the potential to generate $293 \mathrm{~g} \mathrm{~m}^{-2}$ of soil loss, $9.2 \mathrm{~g} \mathrm{~m}^{-2}$ loss of soil organic $\mathrm{C}$, and $1.5 \mathrm{~g} \mathrm{~m}^{-2}$ loss of total $\mathrm{N}$ from patch-burn grazed patches 4 mo after burning. These findings suggest that if intense rainstorms occur in the period between patch burning and vegetation full recovery, risks for runoff and sediment loss from patch-burned areas followed by grazing could be high.

The increased runoff and sediment loss from recently burned patches is attributed to the reduced canopy cover, increased bare ground, and reduced litter cover (Fig. 1). This negative correlation of surface cover with runoff and sediment loss corroborates the critical role of vegetation cover in reducing water erosion, which has been widely documented in the literature (Campo et al., 2006; Larsen et al., 2009). Reduced vegetation cover makes the soil more susceptible to erosion (Zhou et al., 2010). Vegetation cover intercepts raindrops, reduces splash erosion, reduces surface sealing, delays runoff, and promotes water infiltration, reducing runoff and soil loss. The increased runoff rates from burned plots also suggest that burning of pastures reduced water infiltration near the soil surface. 


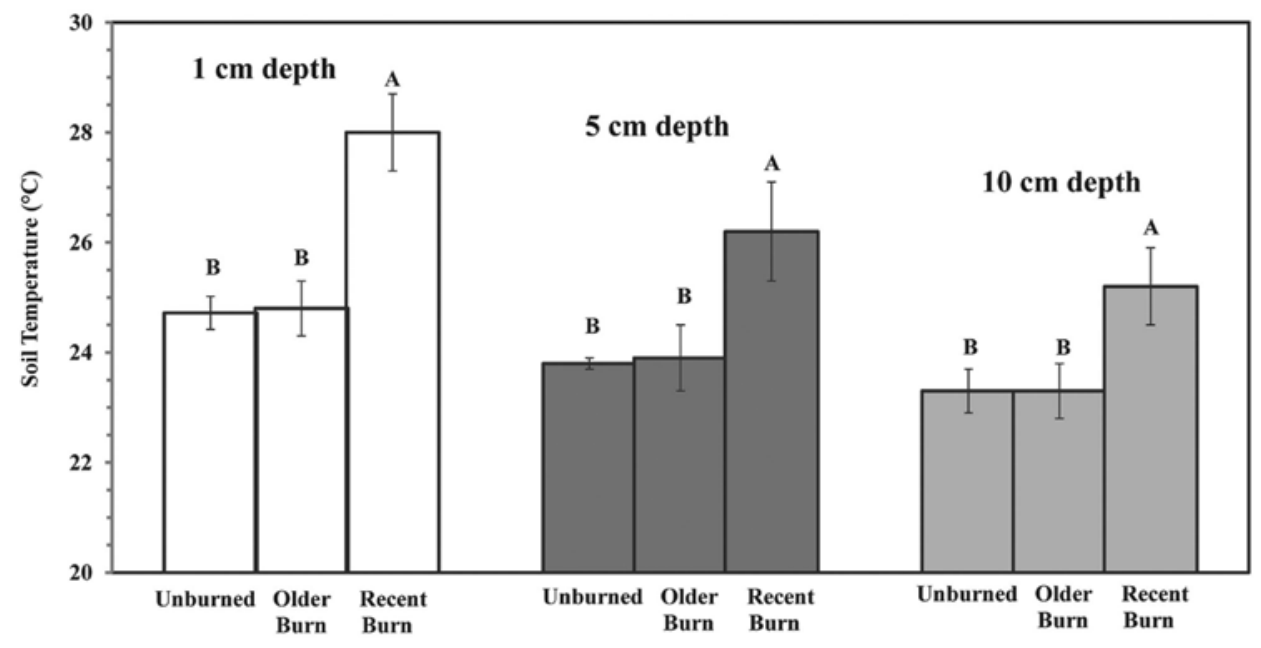

Fig. 4. Patch burning effects on soil temperature for three soil depths measured 4 mo after burning (recently burned patches) and 16 mo after burning (older burned patches) relative to unburned patches within a patch-burn experiment in eastern Nebraska. Means followed by different uppercase letters are significantly different. The error bars are the SD of the mean.

Patch burning increased losses of only runoff and sediment (Fig. 2AC) and not losses of dissolved nutrients (Table 1). Some studies from wildfire events have found high losses of dissolved nutrients (i.e., ammonium, nitrates, and ortho-P concentrations) in runoff after burning (Miller et al., 2013). The use of both controlled fire and the single fire event in our study may explain the lack of significant effects on water quality parameters. Our study suggests that a single fire event followed by intensive grazing may not have significant effects on water quality parameters such as dissolved $\mathrm{C}$, dissolved $\mathrm{P}$, and total $\mathrm{P}$.

Table 1. Runoff water quality parameters as affected by time after burning relative to unburned patches within a patch-burn experiment in eastern Nebraska. Time after burning effects were not significant at $<0.05$.

\begin{tabular}{|c|c|c|c|}
\hline Parameter & Unburned & Older burn ${ }^{t}$ & Recent burn \\
\hline $\mathrm{pH}$ & $6.91 \pm 0.13^{\ddagger}$ & $6.94 \pm 0.14$ & $6.88 \pm 0.14$ \\
\hline Electrical conductivity, $\mathrm{dS} \mathrm{m}^{-1}$ & $0.84 \pm 0.06$ & $0.79 \pm 0.11$ & $0.85 \pm 0.07$ \\
\hline Dissolved organic $\mathrm{C}, \mathrm{mg} \mathrm{L}^{-1}$ & $9.01 \pm 1.27$ & $7 \cdot 50 \pm 3.41$ & $5.08 \pm 0.73$ \\
\hline Dissolved P, mg L-1 & $0.20 \pm 0.13$ & $0.50 \pm 0.64$ & $0.15 \pm 0.13$ \\
\hline Total P, mg L-1 & $0.42 \pm 0.19$ & $1.09 \pm 1.29$ & $0.35 \pm 0.29$ \\
\hline
\end{tabular}

† Older burn, 16 mo after burning; recent burn, 4 mo after burning.

* Values are means $\pm \mathrm{SD}$. 


\section{Soil Physical Properties, Soil Organic C, and Total N}

Time after patch burning did not affect soil bulk density, penetration resistance, wet aggregate stability, and concentrations of soil organic $\mathrm{C}$ and total $\mathrm{N}$ relative to unburned patches. Mean values across treatments and years were $1.21 \pm 0.19 \mathrm{Mg} \mathrm{m}^{-3}$ (mean $\pm \mathrm{SD}$ ) for bulk density, $4.40 \pm 0.31$ MPa for penetration resistance, $4.84 \pm 0.83 \mathrm{~mm}$ for wet aggregate stability, $25.6 \pm 0.08 \mathrm{~g} \mathrm{~kg}^{-1}$ for soil organic $\mathrm{C}$, and $2.5 \pm 0.01 \mathrm{~g} \mathrm{~kg}^{-1}$ for total $\mathrm{N}$ for the $0-$ to $7.5-\mathrm{cm}$ depth. Mean values across treatments and years for soil water content were $0.29 \pm 0.02 \mathrm{~m}^{3} \mathrm{~m}^{-3}$ for the 0 - to $10-\mathrm{cm}$ depth and $0.27 \pm 0.02 \mathrm{~m}^{3} \mathrm{~m}^{-3}$ for the 10 - to 20 -cm depth.

The recently burned patches, however, had consistently higher soil temperature than older burned and unburned patches for the 1-, 5-, and 10-cm soil depths (Fig. 4). Soil temperature did not differ between older burned and unburned patches. Soil temperature in recently burned patches was 2 to $4^{\circ} \mathrm{C}$ higher than in older burned and unburned patches. These results suggest that more bare ground and less canopy cover and litter cover (Fig. 1) probably led to increased soil temperature in the recently burned patches (Fig. 4). Our results agree with Vermeire et al. (2005), who reported that patch-burned grazed plots had 1 to $3^{\circ} \mathrm{C}$ higher soil temperature when measured in May, June, July, and August after a mid-November burn and a mid-April burn in northwestern Oklahoma. In the Sandhills of Nebraska, Volesky and Connot (2000) also reported that soil temperature measured during March through May was $1.6^{\circ} \mathrm{C}$ higher than unburned plots in the $15^{-}$and $30-\mathrm{cm}$ soil depths when wildfires occurred in September of the previous year. The increased soil temperature with patch burning may stimulate plant growth, contribute to vegetation recovery, and enhance microbial activity, but it may also increase evaporation and reduce soil water content (Vermeire et al., 2005; Augustine et al., 2010). In this study, however, soil water content in the $\mathrm{O}$ - to 20-cm depth did not differ among treatments. Mean volumetric water content across treatments for the $\mathrm{o}-$ to $20-\mathrm{cm}$ depth during the field measurements was $0.28 \pm 0.15 \mathrm{~m}^{3} \mathrm{~m}^{-3}$ (mean $\pm \mathrm{SD}$ ).

Our hypothesis that patch burning alters near-surface soil properties by reducing the amount of canopy cover and litter was not supported by the data except soil temperature. These results suggest that grassland ecosystems could be highly resistant and that a single fire may not be sufficient to impart significant changes in most soil physical properties even in the upper few centimeters of soil surface. For example, mean weight 
diameter of water-stable aggregates in the patch-burn and grazed plots $(4.84 \pm 0.83 \mathrm{~mm})$ was larger than that commonly found in most cultivated soils in this region $(<3.5 \mathrm{~mm}$ ) (Blanco-Canqui et al., 2014).

In this study we report soil response to a single fire. We submit that changes in soil properties could be measurable if the same patches were subjected to more burn events followed by intensive grazing. Although patch burning reduced vegetation cover, the percentage of bare ground on recently burned patches was only $33 \pm 7.6 \%$ (Fig. 1), which indicates that burned and grazed patches had sufficient litter cover to maintain soil properties. In contrast, the litter cover in recently burned patches appeared not to be sufficient to protect soil from water erosion (Fig. 2 and 3).

Previous studies also have found small or no effects of patch burning on soil physical properties. In grazed pastures of northcentral Texas, Teague et al. (2008) observed lower penetration resistance and bulk density in unburned plots relative to burned plots, but aggregate stability was unaffected. In the same region, Teague et al. (2010) reported no differences in soil temperature, bulk density, penetration resistance, and aggregate stability among burn and grazing practices. They suggested that the high amount of rainfall (above average) and the rapid restoration of the vegetation cover in the burned areas may explain the lack of changes in soil properties. Our results and those from Teague et al. (2008, 2010) suggest that patch burning may not have detrimental effects on soil physical properties under rapid vegetation recovery or adequate plant growth.

The lack of significant differences in bulk density and penetration resistance in this short-term study suggests that grazing impacts on burned patches did not increase risks of compaction. Some studies have reported that increased intensity of grazing and trampling can alter soil physical properties particularly near the soil surface (Thurow, 1991; Zhou et al., 2010), but others have found limited or no effects. For example, Savadogo et al. (2007) found that prescribed burning and five grazing intensities (zero, light, moderate, heavy, and very heavy) had no significant effect on soil properties.

Likewise, the lack of significant differences in soil water content indicates that patch burning may have limited or no effect on reducing soil water content in spite of reduced vegetation cover and increased soil temperature with burning and grazing. Our results agree with those of Vermeire et al. (2005), who did not observe significant changes in soil water content between patch-burned and unburned treatments in northwestern Oklahoma in a 2-yr patch-burn grazing study. However, in the Flint 
Hills of Kansas, Anderson (1965) reported some differences in soil water content at deeper depths $(>30 \mathrm{~cm})$ in the soil profile between burned and unburned plots after many years of annual burning. These results suggest that repeated burning for many years may impart changes in soil water content relative to one or two burn events.

The results from this study indicate, in general, that patch burning had a significant effect on runoff and sediment loss but not on soil properties. This deserves further discussion. Our results come from a single fire and a single data collection time point. We hypothesize that effects of patch burning on soil parameters may not only differ from year to year but also from season to season within the same year after burn dates (Vermeire et al., 2005). Variations in precipitation input from year to year may affect patch-burning impacts on soil cover and properties. Long-term monitoring of changes in water erosion and soil properties is needed to conclusively ascertain the impacts of patch burning on soil and the environment.

\section{Conclusions}

The effects of patch burning of mixed-grass pasture in eastern Nebraska on soil erosion appeared to be limited to recently burned patches because of lower plant canopy cover and a higher percentage of bare soil. Results indicated that the open canopy of the recently burned patch is likely a cause of accelerated losses of runoff, sediment, and sediment-associated $\mathrm{C}$ and $\mathrm{N}$, but losses in older burned patches were similar to unburned patches. The open canopy and the relatively high percentage of bare soil on the recently burned patches were likely a combined result of the spring fire and the high concentration of cattle attracted to the fresh growth on the burned patch. Near-surface soil physical properties and soil organic $\mathrm{C}$ and total $\mathrm{N}$ concentrations were unaffected by time after patch burning relative to unburned patches. Long-term monitoring of changes in soil properties and soil erosion under patch burning systems is needed across different climate conditions and different seasons and years to further evaluate how patch burning followed by grazing alters soil and environment and sustainability of grassland ecosystems. We hypothesize that patch burning in drier years or drier regions may have more severe impacts and that vegetation recovery may be slower than those observed in this study. 


\section{References}

Anderson, K.L. 1965. Time of burning as it affects soil moisture in an ordinary upland bluestem prairie in the flint hills. J. Range Manage. 18:311-316. doi:10.2307/3895421

Augustine, D.J., J.D. Derner, and D.G. Milchunas. 2010. Prescribed fire, grazing and herbaceous plant production in shortgrass steppe. Rangeland Ecol. Manag. 63:317-323. doi:10.2111/REM-D-09-00044.1

Blanco-Canqui, H., R.B. Ferguson, C.A. Shapiro, R.A. Drijber, and D.T. Walters. 2014. Does inorganic nitrogen fertilization improve soil aggregation? Insights from long-term tillage experiments. J. Environ. Qual. 43:995-1003. doi:10.2134/jeq2013.10.0431

Blanco-Canqui, H., C.J. Gantzer, S.H. Anderson, E.E. Alberts, and A.L. Thompson. 2004. Grass barriers and vegetative filters strip effectiveness in reducing runoff, sediment, and nutrient loss. Soil Sci. Soc. Am. J. 68:16701678. doi:10.2136/sssaj2004.1670

Bray, R.H., and L.T. Kurtz. 1945. Determination of total, organic and available forms of phosphorus in soils. Soil Sci. 59:39-45. doi:10.1097/00010694-194501000-00006

Campo, J., V. Andreu, E. Gimeno-Garcia, O. Gonzalez, and J.L. Rubio. 2006. Occurrence of soil erosion after repeated experimental fires in a Mediterranean environment. Geomorphology 82:376-387. doi:10.1016/j. geomorph.2006.05.014

Fuhlendorf, S.D., and D.M. Engle. 2004. Application of the fire-grazing interaction to restore a shifting mosaic on tallgrass prairie. J. Appl. Ecol. 41:604-614. doi:10.1111/j.0021-8901.2004.00937.x

Grossman, R.B., and T.G. Reinsch. 2002. Bulk density and linear extensibility. In: J.H. Dane and G.C. Topp, editors, Methods of soil analysis. Part 4. SSSA Book Ser. 5. SSSA, Madison, WI. p. 201-225.

Humphry, J.B., T.C. Daniel, D.R. Edwards, and A.N. Sharpley. 2002. A portable rainfall simulator for plot-scale runoff studies. Appl. Eng. Agric. 18:199-204. doi:10.13031/2013.7789

Johansen, M.P., T.E. Hakonson, and D.D. Breshears. 2001. Post-fire runoff and erosion from rainfall simulation: Contrasting forests with shrublands and grasslands. Hydrol. Processes 15:2953-2965. doi:10.1002/hyp.384

Johnson, L.C., and J.R. Matchett. 2001. Fire and grazing regulate belowground processes in tallgrass prairie. Ecology 82:3377-3389. doi:10.1890/o012-9658(2001)o82[3377:FAGRBP]2.0.CO;2

Larsen, I.J., L.H. MacDonald, E. Brown, D. Rough, M.J. Welsh, J.H. Pietraszek, Z. Libohova, J.D. Benavides-Solorio, and K. Schaffrath. 2009. Causes of postfire runoff and erosion: Water repellency, cover, or soil sealing? Soil Sci. Soc. Am. J. 73:1393-1407. doi:10.2136/sssaj2007.0432 
Lowery, B., and J.E. Morrison. 2002. Soil penetrometers and penetrability. In: J.H. Dane and G.C. Topp, editors, Methods of soil analysis. Part 4. SSSA Book Ser. 5. SSSA, Madison, WI. p. 363-385.

Miller, W.W., D.W. Johnson, N. Gergans, E.M. Carroll-Moore, R.F. Walker, T.L. Cody, and B. Wone. 2013. Update on the effects of a Sierran wildfire on surface runoff water quality. J. Environ. Qual. 42:1185-1195. doi:10.2134/ jeq2012.0472

Mueller-Dombois, D., and H. Ellenberg. 1974. Aims and methods of vegetation ecology. John Wiley \& Sons, New York.

Murphy, J., and J.P. Riley. 1962. A modified single solution method for the determination of phosphate in natural waters. Anal. Chim. Acta 27:31-36. doi:10.1016/Sooo3-2670(oo)88444-5

Nelson, D.W., and L.E. Sommers. 1996. Total carbon, organic carbon, and organic matter: Laboratory methods. In: D.L. Sparks, editor, Methods of soil analysis. Part 3. SSSA Book Ser. 5. SSSA, Madison, WI. p. 961-1010.

Nimmo, J.R., and K.S. Perkins. 2002. Aggregate stability and size distribution. In: J.H. Dane and G.C. Topp, editors, Methods of soil analysis. Part 4. SSSA Book Ser. 5. SSSA, Madison, WI. p. 317-327.

Rhoades, J.D. 1996. Salinity: Electrical conductivity and total dissolved solids. In: D.L. Sparks, editor, Methods of soil analysis. Part 3. SSSA Book Ser. 5. SSSA, Madison, WI. p. 417-435.

Robichaud, P.R. 2000. Fire effects on infiltration rates after prescribed fire in Northern Rocky Mountain forests, USA. J. Hydrol. 231-232:220-229. doi:10.1016/Soo22-1694(00)00196-7

SAS Institute. 2014. SAS OnlineDoc 9.1.3. http://support.sas.com/ onlinedoc/913/docMainpage.jsp (accessed 18 Jan. 2014).

Savadogo, P., L. Sawadogo, and D. Tiveau. 2007. Effects of grazing intensity and prescribed fire on soil physical and hydrological properties and pasture yield in the savanna woodlands of Burkina Faso. Agric. Ecosyst. Environ. 118:80-92. doi:10.1016/j.agee.2006.05.002

Schacht, W.H., J. Stubbendieck, T.B. Bragg, A.J. Smart, and J.W. Doran. 1996. Soil quality response of reestablished grasslands to mowing and burning. J. Range Manage. 49:458-463. doi:10.2307/4002930

Schmalz, H.J., R.V. Taylor, T.N. Johnson, P.L. Kennedy, S.J. DeBano, B.A. Newingham, and P.A. McDaniel. 2013. Soil morphologic properties and cattle stocking rate affect dynamic soil properties. Rangeland Ecol. Manag. 66:445453. doi:10.2111/REM-D-12-00040.1

Teague, W.R., S.L. Dowhower, S.A. Baker, R.J. Ansley, U.P. Kreuter, D.M. Conover, and J.A. Waggoner. 2010. Soil and herbaceous plant responses to summer patch burns under continuous and rotational grazing. Agric. Ecosyst. Environ. 137:113-123. doi:10.1016/j.agee.2010.01.010 
Teague, W.R., S.E. Duke, J.A. Waggoner, S.L. Dowhower, and S.A. Gerrard. 2008. Rangeland vegetation and soil response to summer patch fires under continuous grazing. Arid Land Res. Manage. 22:228-241. doi:10.1080/15324980802183210

Thomas, G.W. 1996. Soil pH and soil acidity. In: D.L. Sparks, editor, Methods of soil analysis. Part 3. SSSA Book Ser. 5. SSSA, Madison, WI. p. 475-490.

Thurow, T.L. 1991. Hydrology and erosion. In: R.K. Heitschmidt and J.W. Stuth, editors, Grazing management: An ecological perspective. Timber Press, Portland, OR. p. 141-151.

Vermeire, L.T., D.B. Wester, R.B. Mitchell, and S.D. Fuhlendorf. 2005. Fire and grazing effects on wind erosion, soil water content, and soil temperature. J. Environ. Qual. 34:1559-1565. doi:10.2134/jeq2005.0006

Volesky, J.D., and S.B. Connot. 2000. Vegetation response to late growing-season wildfire on Nebraska Sandhills rangeland. J. Range Manage. 53:421-426. doi:10.2307/4003754

Winter, S.L., S.D. Fuhlendorf, C.L. Goad, C.A. Davis, and K.R. Hickman. 2011. Topoedaphic variability and patch burning in sand sagebrush shrubland. Rangeland Ecol. Manag. 64:633-640. doi:10.2111/REM-D-11-00o68.1

Zhou, Z.C., Z.T. Gan, Z.P. Shangguan, and Z.B. Dong. 2010. Effects of grazing on soil physical properties and soil erodibility in semiarid grassland of the Northern Loess Plateau (China). Catena 82:87-91. doi:10.1016/j. catena.2010.05.005 